\title{
PENGEMBANGAN MODUL FISIKA BERBASIS SAVI (SOMATIC, AUDITORY, VISUALIZATION, INTELLECTUALLY) UNTUK MENINGKATKAN MOTIVASI SISWA PADA PEMBELAJARAN FISIKA KELAS X SMK JURUSAN MULTIMEDIA DENGAN TOPIK IMPULS DAN MOMENTUM
}

\author{
Duwita Sekar Indah ${ }^{1}$, Widha Sunarno ${ }^{2}$, Sarwanto $^{3}$ \\ ${ }^{1}$ Program Studi Magister Pendidikan Sains FKIP Universitas Sebelas Maret \\ Surakarta, 57126, Indonesia \\ duwitasekar09@gmail.com \\ ${ }^{2}$ Program Studi Magister Pendidikan Sains FKIP Universitas Sebelas Maret \\ Surakarta, 57126, Indonesia \\ widhasunarno@staff.fkip.uns.ac.id \\ ${ }^{3}$ Program Studi Magister Pendidikan Sains FKIP Universitas Sebelas Maret \\ Surakarta, 57126, Indonesia \\ sarwanto@staff.fkip.uns.ac.id
}

\begin{abstract}
Abstrak
Modul fisika yang mengintegrasikan gaya belajar siswa sangat terbatas, khususnya modul fisika berbasis SAVI untuk SMK. Penelitian ini bertujuan untuk: 1) menganalisis karakteristik modul fisika berbasis SAVI untuk meningkatkan motivasi siswa; 2) menganalisis kelayakan modul fisika berbasis SAVI untuk meningkatkan motivasi siswa; 3) menganalisis efektivitas modul fisika berbasis SAVI terhadap hasil belajar dan motivasi siswa.Jenis penelitian ini merupakan penelitianResearch and Development(R\&D)dengan menggunakan Model Thiagarajan yang terdiri dari 4 tahap yaitu: tahap pendefinisian (define), tahap perencanaan (design), tahap pengembangan (develop), dan tahap penyebaran (disseminate). Modul divalidasi oleh 3 dosen ahli (ahli materi, ahli bahasa, dan ahli media), 2 peer reviewer, dan 2 reviewer. Modul yang dikembangkan diujicoba terbatas pada 10 orang siswa kelas $\mathrm{X}$ Jurusan Multimedia. Setelah direvisi, modul berbasis SAVI diujicoba skala besar pada kelas X MM 1. Teknik analisis data yaitu: 1) analisis angket kebutuhan guru dan siswa untuk mengetahui kebutuhan produk yang dikembangkan; 2) analisis lembar validasi kelayakan modul dengan menabulasi semua komponen data yang diperoleh, menghitung skor rata-rata dari setiap komponen, dan mengategorikannya, untuk kesimpulan digunakan metode cut off score; 3) analisis hasil belajar dan motivasi siswa dengan menabulasi jumlah skor pengumpulan data dibagi skor kriteria dan dikalikan 100 kemudian mengategorikannya, peningkatan motivasi siswa dianalisis menggunakan N-gain score.Berdasarkan hasil penelitian disimpulkan bahwa: 1) karakteristik modul fisika berbasis SAVI yaitu berupa modul cetak yang menggunakan materi impuls dan momentum dengan memuat empat gaya belajar yaitu somatic, auditory, visualization, dan intellectually untuk meningkatkan motivasi siswa antara lain perhatian, relevansi, percaya diri, dan kepuasan;2) modul fisika berbasis SAVI layak digunakan berdasarkan hasil validasi ahli dengan persentase keidealan sebesar 85,0 \%, hasil angket keterbacaan modul oleh siswa modul dinyatakan layak digunakan $(75,4 \%$ )dan hasil respons guru dalam tahap penyebaran modul layak digunakan(79,2\%); 3) modul fisika berbasis SAVI efektif digunakan dalam pembelajaran dengan $80 \%$ nilai hasil belajar siswa mencapai KKM dan dapat meningkatkan motivasi siswa berdasarkan hasil N-gain score sebesar 0,67 dengan kategori peningkatan sedang.
\end{abstract}

Kata Kunci: Modul, SAVI, Motivasi, Impuls, Momentum 


\section{Pendahuluan}

Fisika merupakan salah satu mata pelajaran yang penting sehingga perlu untuk diajarkan sebagai mata pelajaran tersendiri (Permendiknas No 22 tahun 2006). Mata pelajaran fisika dimaksudkan sebagai wahanauntuk menumbuhkan kemampuan berpikir yang bergunauntuk memecahkan permasalahansehari-hari. Selain itu, pembelajaran fisika diberikan dengan tujuanuntuk membekali pengetahuan dan pengalaman siswa agar dapat mengembangkan ilmu pengetahuan dan teknologi. Dengan demikian, pembelajaran fisikadilaksanakan secara inkuiri untuk menumbuhkan kemampuan berpikir, bekerja, dan bersikap ilmiah serta mengomunikasikannyasebagai aspek pentingkecakapan hidup.

Pembelajaran fisika di SMK harus memperhatikan tuntutan dunia kerja (demand driven), dikembangkan dan dilaksanakan mengacu pada pencapaian kompetensi terstandar, mengakui kemampuan yang telah dimiliki oleh siswa melalui mekanisme Recognition of Prior Learning (RPL) dan Recognition of Current Competency (RRC), dilaksanakan secara terintegrasi antara program pembelajaran di sekolah dengan pelatihan di dunia kerja (Sudira, 2006). Peningkatan kualitas pembelajaran di SMK merupakan tuntutan logis dari perkembangan ilmu pengetahuan, teknologi, dan seni (Ipteks) yang sangat pesat serta tuntutan dunia usaha dan dunia industri. Sudira (2006) menyatakan bahwa pembelajaran di SMK masih menyisakan banyak permasalahan, antara lain kebiasaan salah pada tingkat awal penguasaan dasar kompetensi kejuruan dianggap tidak penting. Padahal untuk mendapat hasil pendidikan yang bermutu harus diawali dengan dasar yang kuat dan benar; tidak ada modul belajar secara lengkap sesuai kompetensi dasar dari masing-masing standar kompetensi mata pelajaran; sekolah tidak memahami standar isi; guru tidak mampu menggunakan teknologi multimedia, tidak mampu mengembangkan bahan ajar/modul, tidak bisa menjabarkan kompetensi kunci, standar kompetensi lulusan, standar kompetensi mata pelajaran, kompetensi dasar, menjadi kegiatan pembelajaran yang terintegrasi dan holistik.

Hasil observasi di SMK Giki 1

Surabaya dalam tahap analisis kebutuhan dapat disimpulkan bahwa: (1) hanya $34 \%$ siswa yang termotivasi dalam mengikuti pembelajaran fisika; (2) tidak semua praktikum fisika sudah mempunyai buku panduan; (3) buku pegangan yang disediakan sekolah belum sepenuhnya membantu siswa dalam memahami materi fisika; (4) siswa yang memiliki gaya belajar somatis sebesar $37 \%$, gaya belajar auditori sebesar $26 \%$, gaya belajar visual sebesar 64 $\%$ dan gaya belajar intelektual sebesar $22 \%$; (5) guru tidak menggunakan bahan ajar yang memperhatikan gaya belajar siswa.

Hasil observasi yang telah dilakukanmenunjukkan bahwa motivasi menjadi satu diantara permasalahan yang timbul dalam pembelajaran fisika di SMK. Jika tidak adanya motivasi dalam diri siswa maka akan berdampak pada prestasi belajar siswa. Motivasi sebagai satu diantara hambatan belajar yang berasal dari siswa dapat menyebabkan rendahnya kualitas pendidikan fisika di SMK. Motivasi adalah kekuatan, baik dari dalam maupun dari luar yang mendorong seseorang untuk mencapai tujuan tertentu yang telah ditetapkan sebelumnya (Uno, 2014:1). Siswa akan berusaha mencapai suatu tujuan karena dirangsang oleh manfaat/keuntungan yang akan diperoleh. Pada diri siswa motivasi dapat mempengaruhi siswa sehingga mempunyai semangat untuk aktif agar kegiatan belajar dapat tetap berjalan. Kurangnya motivasi pada diri siswa menyebabkan seorang siswa tidak sungguhsungguh atau kurang bersemangat dalam melaksanakan kegiatan sehingga terhambat dalam mencapai tujuan belajar.

Hasil observasi juga menunjukkan bahwa dalam proses pembelajaran guru tidak memperhatikan gaya belajar siswa. Masing-masing siswa mempunyai gaya belajar yang berbeda. Beberapa gaya belajar 
tersebut diantaranya somatis, auditori, visual, dan intelektual. Upaya peningkatan mutu pendidikan dapat dilakukan dalam berbagai cara. Satu diantaranya adalah pengembangan bahan ajar yang digunakan oleh guru dalam mengajar di kelas. Bahan ajar yang dikembangkan dapat berupa modul. Modul dapat membantu guru dalam mengondisikan kegiatan pembelajaran lebih terencana dengan baik, mandiri, jelas, dan dapat disesuaikan kebutuhan belajar.

Modul yang dibuat sendiri oleh guru ataupun pengajar dapat disesuaikan dengan materi yang akan diajarkan. Pada mata pelajaran fisika, terdapat beberapa materi yang abstrak dan rumit yang membuat siswa kesulitan dalam memahaminya. Dengan bantuan modul diharapkan dapat menjelaskan dan memberi kemudahan dalam menggambarkan materi yang sulit tersebut.

Model SAVI (Somatic, Auditory, Visualization, Intellectually) merupakan model pembelajaran yang memperhatikan berbagai gaya belajar siswa. Pembelajaran SAVI menekankan bahwa belajar haruslah memanfaatkan semua alat indra yang dimiliki siswa. Gilakjani (2011:104) yang menjelaskan bahwa terdapat beberapa siswa yang lebih suka dengan gaya belajar secara visual, sementara yang lain lebih suka dengan gaya belajar secara auditori dan kinestetik. Siswa dapat menggunakan semua indra untuk menerima informasi dalam kegiatan belajar, sehingga siswa memiliki selera tersendiri untuk mencapai hasil yang baik.

Modul fisika berbasis SAVI di SMA tentunya berbeda dengan di SMK. Di SMA, jelas terlihat bahwa setiap langkah pembelajaran ditekankan siswa harus mengembangkan kemampuan berpikirnya. Sedangkan di SMK, modul fisika berbasis SAVI harus dihubungkan dengan penerapan dalam dunia usaha dan industri. Dalam modul harus terdapat bagian khusus yang dapat membantu siswa memraktikkan ilmunya dalam dunia kerja.

Sudjana

mengungkapkan bahwa suatu pembelajaran efektif dapat ditinjau dari segi proses dan hasilnya. Dari segi proses, suatu pembelajaran harus merupakan interaksi dinamis sehingga siswa sebagai subyek belajar mampu mengembangkan potensi yang ada di dalam dirinya secara efektif. Dari segi hasil, pengajaran haruslah menekankan pada tingkat penguasaan tujuan oleh siswa, baik secara kualitas maupun kuantitas. Uno (2014) menyatakan bahwa efektivitas pembelajaran dapat diketahui dengan melihat tingkat ketercapaian tujuan pembelajaran oleh peserta didik. Sejalan dengan Peterson (dalam Soewandi,et al., 2005:44) menyatakan bahwa efektivitas pembelajaran lebih ditekankan pada hasil, yaitu banyaknya hasil belajar yang dapat tercapai, jangka waktu pencapaiannya, dan jangka waktu bertahannya sesuatu.

Satu diantara materi fisika adalah impuls dan momentum. Materi tersebut pemanfaatannya sangat dekat dengan kehidupan siswa. Setiap hari siswa tidak lepas dari pemanfaatan impuls dan momentum. Pembelajaran akan lebih bermakna jika siswa dapat menemukan sendiri konsep materi yang mereka pelajari. Diharapkan apabila siswa memahami proses untuk mendapatkan konsep suatu ilmu yang erat kaitannya dengan kehidupan mereka, maka siswa akan lebih bersemangat dalam mempelajari materimateri lainnya. Selain itu, pemilihan meteri impuls dan momentum ini berdasarkan hasil wawancara dengan guru SMK Giki 1 Surabaya yang menunjukkan bahwa materi tersebut cukup sulit diajarkan karena bersifat abstrak dan tidak tersedianya alat dan bahan serta buku panduan untuk praktikum di sekolah.

Permasalahan di atas menunjukkan bahwa diperlukannya sumber belajar fisika untuk siswa SMK yang memperhatikan gaya belajar siswa agar motivasi belajar fisika meningkat sehingga dilakukan penelitian yang bertujuan untuk menganalisis karakteristik modul fisika berbasis SAVI, menganalisis kelayakan modul fisika berbasis SAVI, dan 
menganalisis efektivitas modul fisika berbasis SAVI terhadap hasil belajar dan motivasi siswa.

\section{Metode Penelitian}

Jenis penelitian yang digunakan yaitu Research and Development (R\&D) dengan menggunakan 4-D Model Thiagarajan (1974) yang terdiri dari 4 tahap yaitu: tahap pendefinisian (define), tahap perencanaan (design), tahap pengembangan (develop), dan tahap penyebaran (disseminate). Penelitian dilakukan di Kampus Pascasarjana UNS dan SMK Giki 1 Surabaya.

Pada tahap pendefinisian dilakukan analisis untuk mengetahui permasalahan mendasar pada pembelajaran di sekolah, karakteristik siswa, mengidentifikasi materi yang digunakan, mengidentifikasi tugas dan tujuan pembelajaran. Pada tahap perencanaan disusun instrumen yang digunakan, pemilihan media berupa modul fisika berbasis SAVI, pemilihan format dan rancangan awal dari modul yang dikembangkan. Pada tahap pengembangan, modul divalidasi oleh 3 dosen ahli (ahli materi, ahli bahasa dan ahli media), 2 peer reviewer dan 2 reviewer. Modul berbasis SAVI yang dikembangkan diujicoba terbatas pada 10 orang siswa Kelas $\mathrm{X}$ Jurusan Multimedia. Setelah direvisi, modul berbasis SAVI diujicoba skala besar pada Kelas X MM 1 dengan jumlah siswa 35 siswa. Pada tahap penyebaran dilakukan penyebaran modul ke beberapa sekolah SMK di Surabaya.

Instrumen pengumpulan data yang digunakan dalam penelitian ini yaitu: angket analisis kebutuhan guru dan siswa; lembar validasi modul oleh validator ahli, peer reviewer, dan reviewer; angket keterbacaan modul oleh siswa; tes kognitif; lembar penilaian afektif; lembar penilaian psikomotor; lembar observasi motivasi; angket motivasi siswa; dan lembar respons guru fisika SMK.

Teknik analisis data dibagi menjadi tiga. 1) Analisis data angket kebutuhan guru dan siswa untuk mengetahui kebutuhan produk yang dikembangkan. 2) Analisis lembar validasi ahli, peer reviewer, reviewer, angket keterbacaan modul oleh siswa dan angket respons guru fisika untuk mengetahui kelayakan modul dengan menabulasi semua komponen data yang diperoleh, menghitung skor rata-rata dari setiap komponen dan mengkategorikannya. Data yang diperoleh kemudian dihitung menggunakan persentase keidealan. Untuk mengetahui kesimpulan digunakan metode cut off score (Winnie, 2009). Modul dinyatakan layak jika persentase keidealan nilai rata-rata seluruh responder $\geq$ nilai $c u t$ off score. 3) Analisis hasil belajar kognitif, afektif, dan psikomotor serta motivasi siswadengan menabulasi jumlah skor pengumpulan data dibagi skor kriteria dan dikalikan 100 dan mengkategorikannya. Untuk mengetahui peningkatan motivasi siswa dianalisis menggunakan $\mathrm{N}$-gain score kemudian nilai $\mathrm{N}$-gain dikategorikan ke dalam kriteria interpretasi dari $\mathrm{N}$-gain score.

\section{Hasil dan Pembahasan}

Penelitian yang telah dilakukan menghasilkan modul fisika berbasis SAVI untuk meningkatkan motivasi siswa pada materi impuls dan momentum SMK Kelas $\mathrm{X}$. Jenis penelitian yang digunakan adalah penelitian dan pengembangan (Research and development $/ R \& D$ ) dengan menggunakan Model 4-D (four D model) dikembangkan oleh Thiagarajan (1974). Hasil dan pembahasan dari penelitian adalah sebagai berikut:

\section{A. Hasil Penelitian}

\section{Tahap Pendefinisian}

Pada tahap ini dilakukan penyebaran angket analisis kebutuhan dan wawancara di SMK Giki 1 Surabaya. Penyebaran angket kebutuhan siswa diberikan kepada 35 siswa Kelas X Jurusan Multimedia. Angket kebutuhan guru dan wawancara dilakukan kepada guru fisika SMK Giki 1 Surabaya terhadap pembelajaran fisika. Hasil observasi dalam 
tahap analisis kebutuhan dapat disimpulkan bahwa: (1) hanya $34 \%$ siswa yang termotivasi dalam mengikuti pembelajaran fisika; (2) tidak semua praktikum fisika sudah mempunyai buku panduan; (3) buku pegangan yang disediakan sekolah belum sepenuhnya membantu siswa dalam memahami materi fisika; (4) siswa yang memiliki gaya belajar somatis sebesar 37 $\%$, gaya belajar auditori sebesar $26 \%$, gaya belajar visual sebesar $64 \%$ dan gaya belajar intelektual sebesar 22\%; (5) guru tidak menggunakan bahan ajar yang memperhatikan gaya belajar siswa.

Hasil analisis kebutuhan menunjukkan bahwa siswa membutuhkan bahan ajar yang dapat memotivasi siswa dan dapat membantu siswa belajar menurut gaya belajar yang mereka miliki. Selain itu bahan ajar diharapkan dapat menjelaskan konsep yang bersifat abstrak dan terdapat panduan praktikum yang dapat membantu siswa dalam memahami materi fisika. Oleh karena itu dikembangkan bahan ajar berupa modul fisika berbasis SAVI dengan materi impuls dan momentum.

\section{Tahap Perencanaan}

Tahap perancangan dilakukan pemilihan media yaitu berupa modul fisika berbasis SAVI untuk meningkatkan motivasi siswa pada materi impuls dan momentum. Format dari desain awal pengembangan modul fisika berbasis SAVI yaitu: 1) halaman sampul berisi judul modul, identitas penulis, dan instansi; 2) halaman francis; 3) kata pengantar; 4) daftar isi; 5) pendahuluan yang terdiri dari deskripsi modul, bagian-bagian modul, kegunaan mata pelajaran, standar kompetensi dan kompetensi dasar, serta petunjuk penggunaan modul; 6) peta konsep; 7) kegiatan belajar yang meliputi: tujuan pembelajaran, prasyarat, kegiatan siswa, diskusi, materi pokok, uraian materi, penerapan materi dalam kehidupan seharihari dan industri, rangkuman, kilas balik materi, dan tugas mandiri; 8) evaluasi; 9) glosarium; 10) daftar pustaka.

\section{Tahap Pengembangan}

Pada tahap ini,modul

dikembangkan berdasarkan desain awal modul yang sudah dibuat pada tahap perencanaan. Modul yang sudah dibuat kerangka dan desainnya kemudian diisi dengan materi impuls dan momentum. Setelah modul jadi, divalidasikan kepada validasi ahli, peer reviewer, dan reviewer untuk dinilai kelayakan modul.

\section{Validasi Ahli}

Validasi ahli terdiri dari tiga validasi yaitu ahli materi, ahli bahasa dan ahli media.

a. Ahli Materi

Komponen yang dinilai dalam validasi materi yaitu meliputi kesesuaian materi dengan Kompetensi Dasar (KD), kebenaran konsep materi dan penggunaan fakta dalam contoh, kontekstualitas materi, kesesuaian penyajian materi dengan gaya belajar dan ketertarikan siswa terhadap materi. Berdasarkan hasil validasi diperoleh persentase keidealan untuk materi sebesar $85,9 \%$ dengan kriteria baik. Saran dan komentar dari validator ahli materi tersaji dalam tabel 1 .

Tabel 1. Saran dan Komentar Ahli Materi

\begin{tabular}{cl}
\hline No. & \multicolumn{1}{c}{ Saran dan Komentar } \\
\hline 1 & $\begin{array}{l}\text { Contoh momentum diambilkan dari kegiatan } \\
\text { yang dapat dilakukan siswa sendiri }\end{array}$ \\
\hline 2 & $\begin{array}{l}\text { Contoh impuls diambilkan dari kegiatan } \\
\text { yang dapat diamati siswa secara langsung }\end{array}$ \\
\hline 3 & $\begin{array}{l}\text { Contoh tumbukan diambilkan dari kegiatan } \\
\text { yang dapat dilakukan siswa secara langsung }\end{array}$ \\
\hline 4 & $\begin{array}{l}\text { Sumber gambar diusahakan dari } \\
\text { dokumentasi penulis sendiri }\end{array}$ \\
\hline 5 & Peta konsep alurnya diperbaiki. \\
\hline
\end{tabular}

b. Ahli Bahasa

Komponen yang dinilai dalam validasi bahasa meliputi kesesuaian bahasa dengan kemampuan siswa SMK, keefektifan dan efisiensi penggunaan bahasa, komunikatif, penggunaan ejaan, penggunaan istilah, struktur kalimat, serta konsistensi penggunaan simbol dan nama ilmiah/bahasa asing. Berdasarkan hasil validasi yang telah dilakukan diperoleh persentase keidealan aspek bahasa sebesar 75,0 \% dengan kriteria baik. Saran dan 
komentar dari ahli bahasa guna sebagai masukan untuk perbaikan modul tersaji dalam tabel 2.

Tabel 2. Saran dan Komentar Ahli Bahasa

\begin{tabular}{cl}
\hline No. & \multicolumn{1}{c}{ Saran dan Komentar } \\
\hline 1 & $\begin{array}{l}\text { Perbaiki keefektifan dan koherensi } \\
\text { paragrafnya }\end{array}$ \\
\hline 2 & Penulisan bahasa asing dicetak miring \\
\hline 3 & $\begin{array}{l}\text { Peluruhan kata yang berawalan huruf K, P, T, } \\
\text { dan S diperhatikan }\end{array}$ \\
\hline 4 & Kata pengantar diperjelas dan kurang spesifik \\
\hline 5 & Penggunaan huruf kapital harus diperhatikan \\
\hline
\end{tabular}

c. Ahli Media

Penilaian modul oleh ahli media meliputi warna dan ukuran font, layout, penyajian, dan ilustrasi gambar. Berdasarkan hasil validasi ahli media, diperoleh persentase keidealan aspek media sebesar 95,0 \% dengan kriteria sangat baik. Selain memberikan penilaian berupa skor pada lembar validasi, validator juga memberikan saran dan komentar sebagai masukan untuk perbaikan modul.Saran dan komentar dari ahli media tersaji dalam tabel 3.

Tabel 3. Saran dan Komentar Ahli Media

\begin{tabular}{cl}
\hline No. & \multicolumn{1}{c}{ Saran dan Komentar } \\
\hline 1 & Persamaan diberi nomor urut \\
\hline 2 & Sumber gambar ditulis lengkap \\
\hline 3 & $\begin{array}{l}\text { Penulisan kata 'PhET' harus sesuai sumber } \\
\text { asli }\end{array}$ \\
\hline
\end{tabular}

Setelah mendapatkan saran dan komentar dari validasi ahli kemudian dilakukan perbaikan pada bagian modul yaitu antara lain: 1) contoh-contoh konsep materi diambilkan dari kegiatan yang dapat dilakukan siswa; 2) alur peta konsep; 3) penulisan bahasa asing dicetak miring; 4) peluruhan kata yang berawalan huruf $\mathrm{K}, \mathrm{P}$, $\mathrm{T}$, dan $\mathrm{S}$; 5) penulisan huruf kapital; 6) nomor urut persamaan; 7) kelengkapan sumber gambar; 8) penulisan kata 'PhET' sesuai sumber asli.

\section{Validasi Peer Reviewer dan Reviewer}

Validasi temansejawat (peer reviewer) dilakukan oleh dua mahasiswa Pascasarjana Pendidikan Sains Universitas Sebelas Maret yang sedang dalam proses penyelesaian tugas akhir, sedangkan validasi guru fisika SMK (reviewer) dilakukan oleh dua guru fisika SMK. Penilaian modul oleh peer reviewer dan reviewer meliputi komponen materi, bahasa, serta tampilan dan gambar. Komponen-komponen tersebut kemudian dijabarkan menjadi 34 butir indikator penilaian.

Hasil validasi diperoleh persentase keidealan untuk peer reviewer I sebesar $77,9 \%$ dengan kriteria baik, untuk peer reviewer II sebesar 86,0 \% dengan kriteria sangat baik, untuk reviewer I sebesar 86,8 $\%$ dengan kriteria sangat baik dan untuk reviewer II sebesar 88,2 \% dengan kriteria sangat baik. Saran dan komentar yang diberikan oleh peer reviewer dan reviewertersaji dalam tabel 4.

Tabel 4. Saran dan Komentar Peer Reviewer dan Reviewer

\begin{tabular}{cl}
\hline No. & \multicolumn{1}{c}{ Saran dan Komentar } \\
\hline 1 & $\begin{array}{l}\text { Pada bagian-bagian modul sebaiknya } \\
\text { screenshoot dari save as PDF }\end{array}$ \\
\hline 2 & $\begin{array}{l}\text { Penulisan simbol masih ada yang kurang } \\
\text { konsisten }\end{array}$ \\
\hline 3 & Keterangan gambar lebih lengkap \\
\hline 4 & Satuan pada soal latihan dilengkapi \\
\hline 5 & Penulisan kata disesuaikan dengan EYD \\
\hline 6 & Kunci jawaban tidak perlu ditampilkan \\
\hline 7 & $\begin{array}{l}\text { Penjelasan analisis dalam diskusi percobaan } \\
\text { ditambahi dan diperjelas lagi }\end{array}$ \\
\hline 8 & Notasi skalar dan vektor diperhatikan \\
\hline 9 & $\begin{array}{l}\text { Materi yang digunakan disesuaikan dengan } \\
\text { kapasitas siswa SMK }\end{array}$ \\
\hline 10 & Penggunaan tanda baca diperhatikan \\
\hline 11 & $\begin{array}{l}\text { Tugas media yang diberikan sesuai dengan } \\
\text { kompetensi yang dimiliki siswa }\end{array}$ \\
\hline 12 & $\begin{array}{l}\text { Penggunaan contoh sesuai dengan kehidupan } \\
\text { sehari-hari }\end{array}$ \\
\hline
\end{tabular}

Saran dan komentar dari peer reviewer dan reviewer kemudian digunakan untuk perbaikan modul. Bagian modul yang diperbaiki setelah divalidasikan kepada peer reviewer dan reviewer antara lain: 1) screenshoot bagian-bagian modul save as dari PDF; 2) simbol konsisten; 3) kelengkapan keterangan gambar; 4) kelengkapan satuan pada soal; 5) kesesuaian kata dan tanda baca dengan aturan. 
Hasil validasi dari keseluruhan validator dihitung menggunakan metode $c u t$ off score (Winnie, 2009) untuk mengetahui kelayakan draf I modul fisika berbasis SAVI yang telah dikembangkan. Modul dikategorikan layak berdasarkan nilai ratarata sebesar 85,0 \% lebih besar dari pada nilai cut off score yang mempunyai nilai 84,7 \%.Modul yang sudah divalidasi dan diperbaiki kemudian digunakan dalam uji coba di sekolah.

\section{Uji Coba Modul}

Uji coba modul dilakukan dua tahap yaitu uji coba terbatas dan uji coba skala luas.

a. Uji Coba Terbatas

Tujuan dari uji coba terbatas untuk mengetahui keterbacaan modul oleh siswa. Modul diujicobakan kepada 10 orang siswa kelas X Jurusan Multimedia SMK. Setelah mempelajari modul, kemudian siswa mengisi angket keterbacaan modul dan memberikan saran dan komentar pada lembar penilaian yang telah disediakan. Berdasarkan angket keterbacaan modul hasil uji coba terbatas diperolehpersentase keidealan keterbacaan modul sebesar 75,4 $\%$ lebih besar daripada nilai cut off score yaitu 75,0 \%.Hal ini menunjukkan bahwa modul dikategorikan layak digunakan.

Perbaikan dilakukan karena terdapat kesalahan dan ketidakjelasan yang membuat siswa kurang memahami maksud dari modul. Perbaikan yang dilakukan setelah uji coba terbatas dijabarkan sebagai berikut:

1) Tugas mandiri pada KB I membuat video diperbaiki menjadi membuat scene video (alur pembuatan video) contoh penerapan dalam kehidupan sehari-hari yang menjelaskan salah satu konsep tersebut secara mandiri.

2) Diskusi pada KB I ditambahkan cara menemukan persamaan garis berdasarkan grafik yang telah dibuat.

3) Gambar interaksi dua partikel di modul ditambahkan gambar sebelum partikel tersebut berinteraksi.
4) Rancangan percobaan tumbukan lenting sempurna dilengkapi dengan rancangan sebelum bola bertumbukan.

b. Uji Coba Skala Luas

Uji coba dilakukan pada kelas $\mathrm{X}$ MM 1 SMK Giki 1 Surabaya dengan jumlah siswa sebanyak 35 siswa. Pada tahap ini uji coba dilakukan dengan dua kali pertemuan. Masing-masing pertemuan siswa diberi pembelajaran sesuai dengan RPP yang telah dibuat pada tahap perancangan. Pada tahap ini, data yang diambil adalah hasil belajar kognitif, afektif, psikomotor, dan motivasi siswa.

Hasil penilaian kognitif siswa diperoleh nilai rata-rata sebesar 70 . Sedangkan untuk penilaian afektif, terdapat tiga aspek yang diamati yaitu rasa ingin tahu, teliti, dan bekerja sama dalam kelompok. Berdasarkan hasil observasi dan dilakukan analisis perhitungan, diperoleh nilai afektif siswa untuk aspek rasa ingin tahu sebesar 84, untuk aspek teliti sebesar 75, dan untuk aspek bekerja sama dalam kelompok sebesar 85 dengan kriteria keseluruhan aspek baik. Rata-rata penilaian afektif siswa secara keseluruhan adalah sebesar 81 dengan kriteria baik.

Penilaian psikomotor siswa, terdapat tiga aspek yang diamati yaitu menyiapkan alat dan bahan percobaan, membaca data percobaan dan membuat grafik hasil percobaan. Berdasarkan hasil observasi dan dilakukan analisis perhitungan, diperoleh nilai psikomotor siswa masing-masing aspek yaitu untuk aspek menyiapkan alat dan bahan percobaan sebesar 86, untuk aspek membaca data percobaan sebesar 76, dan untuk aspek membuat grafik hasil percobaan sebesar 71 dengan kriteria keseluruhan aspek baik. Rata-rata penilaian psikomotor siswa secara keseluruhan adalah sebesar 78 dengan kriteria baik.

Hasil penilaian kognitif, afektif, dan psikomotor siswa diperoleh nilai ratarata keseluruhan hasil belajar sebesar 76 . KKM mata pelajaran fisika di SMK Giki Surabaya sebesar 72. Berdasarkan hasil analisis dapat diketahui sebesar 28 siswa 
(80 \%) mencapai KKM dan 7 siswa (20\%) belum mencapai KKM.

Data untuk mengetahui motivasi siswa diperoleh dari lembar observasi dan angket respons motivasi siswa. Terdapat empat aspek motivasi yang diukur antara lain attention (perhatian), relevance (relevansi), confidence (percaya diri), dan satisfaction (kepuasan). Masing-masing aspek dijabarkan menjadi dua indikator penilaian, sehingga terdapat 8 butir penilaian motivasi baik dalam lembar observasi maupun angket respons siswa. Berdasarkan data kemudian dilakukan perhitungan diperoleh nilai masing-masing aspek. Perbandingan hasil angket respons siswa dan observasi motivasi siswa

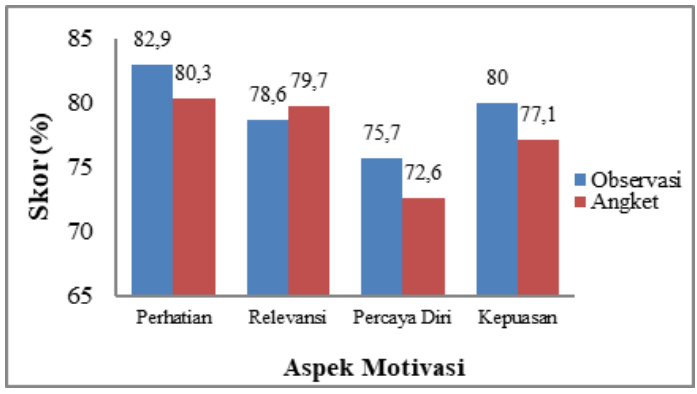

disajikan dalam gambar 1.

Gambar 1. Grafik Hasil Penilaian Motivasi Siswa

Data tersebutkemudian dirata-rata kembali dan diperoleh rata-rata keseluruhan motivasi siswa dari observasi dan angket sebesar 78,4 \%. Hasil observasi sebelum dilakukan pembelajaran dengan menggunakan modul, diketahui hanya $34 \%$ siswa yang termotivasi dan setelah diberikan pembelajaran dengan mengunakan modul, motivasi siswa meningkat menjadi 78,4\%. Hasil perhitungan $\mathrm{N}$-gain nilai motivasi siswa sebelum pembelajaran dan sesudah pembelajaran diperoleh nilai $\mathrm{N}$-gain sebesar 0,67. Menurut kriteria interpertasi nilai $\mathrm{N}$-gain Hake (1998), penilaian tersebut termasuk dalam kategori peningkatan sedang.

Perbaikan dilakukan karena terdapat kesalahan dan ketidakjelasan yang membuat siswa kurang memahami maksud dari modul. Perbaikan yang dilakukan setelah uji coba skala besar dijabarkan sebagai berikut:
1) Tugas mandiri pada KB I membuat dari membuat scene video diperbaiki menjadi silde power point materi impuls dan momentum secara mandiri.

2) Diskusi pada KB I untuk mencari persamaan garis lebih disederhanakan

3) Barcode pada contoh gambar dihilangkan

4) Urutan koefisien restitusi diturunkan dari kekekalan energi dan kekekalan momentum pada penjelasan tumbukan lenting sempurna

Hasil dari uji coba skala yang sudah diperbaiki kemudian digunakan untuk tahap desiminasi (penyebaran).

\section{Tahap Penyebaran}

Tahap akhir dilakukan untuk menyebarluaskan modul sebagai produk dari pengembangan agar dapat digunakan dalam pembelajaran di sekolah. Teknik penyebaran yang dipakai adalah dengan mengirim modul kepada seorang responden guru fisika. Responden guru fisika diambil secara acak di wilayah Surabaya. Modul yang dikirim dilengkapi dengan angket. Hasil angket dikirim kembali kepada peneliti untuk dijadikan masukan perbaikan modul. Adapun sekolah yang menjadi tempat penyebaran modul antara lain SMKN 1 Surabaya, SMKN 3 Surabaya, SMKN 6 Surabaya, SMK Ketintang Surabaya, SMK IKIP Surabaya, dan SMK Trisila Surabaya.

Angket respons guru pada tahap penyebaran berupa penilaian dari guru fisika SMK terhadap modul yang telah dikembangkan untuk mengetahui tampilan dan keterbacaan modul fisika berbasis SAVI. Berdasarkan hasil penyebaran modul, diperoleh respons guru mendapat respons baik dengan persentase keidealan $79,2 \%$ yang termasuk dalam kategori layak digunakan. Saran dan komentar yang diberikan digunakan sebagai masukan untuk perbaikan modul antara lain sebagai berikut: 
1) Gambar ilustrasi masih ingatkah kamu sebaiknya diberi warna

2) Tanda positif dan negatif pada penurunan persamaan untuk mencari koefisien restitusi dicek kembali

3) Kunci jawaban sebaiknya tidak dicantumkan

4) Ilustrasi gambar permainan kelereng sebaiknya diperbaiki

5) Disesuaikan dengan kurikulum terbaru.

\section{B. Pembahasan}

1. Karakteristik Modul Fisika Berbasis SAVI untuk Meningkatkan Motivasi Siswa

Modul fisika berbasis SAVI (Somatic, auditory, visualization, intellectually) untuk meningkatkan motivasi siswa pada materi impuls dan momentum dikembangkan berdasarkan prosedur pengembangan Model 4-D (four D model) dikembangkan oleh Thiagarajan (1974). Modul dikemas dalam bentuk cetak. Modul fisika berbasis SAVI merupakan modul yang dapat membantu siswa dalam mengonstruksi pengetahuan sesuai gaya belajar masing-masing siswa.

Novitayani (2015) menyatakan modul fisika berbasis SAVI pada materi kalor dan perpindahannya dikembangkan menggunakan tahap pembelajaran SAVI, yang meliputi (a) tahap persiapan dapat dilakukan dengan cara siswa mengamati dan membaca fenomena yang disajikan dalam modul; (b) tahap penyampaian dapat dilakukan dengan cara siswa melakukan eksperimen berdasarkan alat dan bahan serta prosedur kerja; (c) tahap pelatihan dapat dilakukan dengan cara siswa melakukan analisis data menurut variabel yang diukur; dan (d) tahap penampilan hasil dapat dilakukan dengan cara siswa membuat kesimpulan berdasarkan analisis data, kemudian siswa menampilkan hasil pekerjaannya di depan kelas

Pembelajaran SAVI menekankan bahwa belajar haruslah memanfaatkan semua alat indra yang dimiliki siswa (Shoimin, 2013:179). Modul ini memuat empat gaya belajar tersebut untuk meningkatkan motivasi siswa dalam belajar yang ditunjukkan dengan ikon tertentu. Menurut Meier, belajar bisa optimal jika keempat unsur SAVI ada dalam satu peristiwa pembelajaran. Seorang siswa dapat belajar sedikit dengan menyaksikan presentasi (V), tetapi ia dapat belajar jauh lebih banyak jika dapat melakukan sesuatu ketika presentasi sedang berlangsung (S), membicarakan topik yang mereka pelajari (A), dan memikirkan cara menerapkan informasi dalam presentasi tersebut untuk menyelesaikan masalah-masalah yang ada (I).

Aspek motivasi yang ditingkatkan yaitu attention (perhatian), relevance (relevansi), confidence (percaya diri), dan satisfaction (kepuasan). Aspek-aspek tersebut dapat digunakan untuk mengukur motivasi siswa seperti yang telah dikembangkan oleh Keller. Keller mengungkapkan, motivasi belajar yang sistematis, efektif, serta disesuaikan dengan keinginan mampu memecahkan suatu permasalahan.

Modul fisika berbasis SAVI berarti modul tersebut dapat membantu siswa dalam mengontruksi pengetahuan sesuai gaya belajar masing-masing siswa. Pembelajaran SAVI menekankan bahwa belajar haruslah memanfaatkan semua alat indera yang dimiliki siswa. Modul fisika berbasis SAVI dikembangkan berdasarkan KD 5.1 Mengenali jenis tumbukan, KD 5.2 Menguasai konsep impuls dan hukum kekekalan momentum, dan KD 5.3 Menerapkan hubungan impuls dan momentum dalam perhitungan.

\section{Kelayakan Modul Fisika Berbasis SAVI untuk Meningkatkan Motivasi Siswa}

Modul merupakan salah satu bentuk bahan ajar yang dikemas secara utuh dan sistematis, di dalamnya memuat seperangkat pengalaman belajar yang terencana dan didesain untuk membantu peserta didik menguasai tujuan belajar yang spesifik (Daryanto, 2013:9). Modul berfungsi sebagai sarana belajar yang bersifat mandiri, sehingga siswa dapat 
belajar secara mandiri sesuai dengan kecepatan masing-masing.

Pembelajaran SAVI menekankan bahwa belajar haruslah memanfaatkan semua alat indra yang dimiliki siswa. Setiap siswa memiliki gaya belajar berbeda-beda. Modul fisika berbasis SAVI berarti modul tersebut dapat membantu siswa dalam mengkontruksi pengetahuan sesuai gaya belajar masing-masing siswa. Kelayakan modul fisika berbasis SAVI telah diuji melalui tahap validasi yang divalidasi oleh dosen ahli materi, ahli bahasa, ahli media, teman sejawat (peer reviewer), dan guru fisika SMK (reviewer).

Hasil validasi seluruh aspek menyatakan modul fisika berbasis SAVI masuk dalam kategori layak. Purwadarminto (1989) menyatakan kelayakan adalah kondisi atau keadaan sudah pantas. Kelayakan diukur dengan pemenuhan kriteria modul. Selain hasil validasi, kelayakan modul fisika berbasis SAVI juga didukung oleh hasil angket keterbacaan modul oleh siswa dalam uji coba terbatas dan respons guru dalam tahap penyebaran modul. Keduanya menyatakan modul layak digunakan.

\section{Modul fisika berbasis SAVI} dinyatakan layak meskipun masih memerlukan perbaikan berdasarkan saran dan rekomendasi validator. Revisi dilakukan agar modul semakin baik dan sesuai dengan kriteria modul. Revisi modul meliputi: a) contoh-contoh konsep materi diambilkan dari kegiatan yang dapat dilakukan siswa sendiri; b) alur peta konsep; c) penulisan bahasa asing dicetak miring; d) peluruhan kata yang berawalan huruf $\mathrm{K}, \mathrm{P}, \mathrm{T}$, dan $\mathrm{S}$; e) penulisan huruf kapital; f) nomor urut persamaan; g) kelengkapan sumber gambar; h) penulisan kata 'PhET' sesuai sumber asli; i) screenshoot bagian-bagian modul save as dari PDF; j) simbol konsisten; k) kelengkapan satuan pada soal; 1) kesesuaian kata dan tanda baca dengan aturan.

Hasil penelitian yang dilakukan oleh Novitayani (2015) menunjukkan bahwa modul fisika berbasis SAVI pada materi kalor dan perpindahannya layak digunakan sebagai bahan ajar. Modul fisika berbasis SAVI ini berada pada kriteria sangat baik. Selain itu, pembelajaran menggunakan modul Fisika berbasis SAVI dapat meningkatkan kreativitas belajar siswa dengan kriteria gain ternormalisasi sedang. Sejalan dengan Pratiwi (2013), menunjukkan bahwa terdapat perbedaan yang signifikan antara hasil belajar fisika siswa pada kelas yang menggunakan model temuan terbimbing disertai model SAVI dengan kelas yang tidak menggunakan model temuan terbimbing disertai model SAVI. Hal ini dikarenakan dengan menggunakan model temuan terbimbing disertai model SAVI, siswa dapat mengonstruksi pengetahuan berdasarkan pengalaman, sehingga siswa akan lebih paham dengan konsep yang telah dipelajari.

\section{Efektivitas Modul Fisika Berbasis SAVI terhadap Hasil Belajar dan Motivasi Siswa}

Pada tahap pengembangan di kegiatan uji coba skala luas dilakukan penilaian motivasi pada 35 siswa kelas $\mathrm{X}$ MM 1 SMK Giki 1 Surabaya. Motivasi tidak dapat diamati secara langsung, tetapi dapat diinterpretasikan dalam tingkah laku seseorang. Motivasi dapat diketahui dari respons siswa dalam mengikuti proses pembelajaran. Untuk mengetahui termotivasinya siswa dalam pembelajaran, pada penelitian ini diukur dengan menggunakan instrumen berupa angket respons siswa dan lembar observasi siswa selama proses pembelajaran.

Hasil kedua instrumen penilaian motivasi siswa, skor paling tinggi pada aspek perhatian. Hal ini dikarenakan pada aspek perhatian mudah dilakukan oleh siswa. Ketika siswa memerhatikan pembelajaran dan mengajukan pertanyaan sudah termasuk dalam indikator aspek perhatian. Sedangkan skor paling rendah pada aspek percaya diri. Siswa kurang percaya diri dan ragu-ragu dalam mengerjakan setiap tugas yang ada dalam modul. Untuk aspek relevansi, siswa sudah dapat menghubungkan materi dengan 
kegiatan maupun contoh yang ada dalam kehidupan sehari-hari dan dunia industri. Selain itu siswa juga merasa puas ketika dapat mengerjakan tugas-tugas yang ada di dalam modul maupun ketika menjawab pertanyaan yang diajukan guru.

Peningkatan motivasi dapat diketahui dari peningkatan nilai motivasi sebelum dilakukan pembelajaran dengan menggunakan modul dan setelah dilakukan pembelajaran yang sudah dihitung nilai $\mathrm{N}$ gainnya. Berdasarkan hasil perhitungan, diperoleh nilai $\mathrm{N}$-gain termasuk dalam kategori peningkatan sedang.

Trianto (2009:241) menyatakan berdasarkan ketentuan KTSP penentuan ketuntasan belajar ditentukan sendiri oleh masing-masing sekolah yang dikenal dengan kriteria ketuntasan minimal (KKM) dengan berpedoman pada tiga pertimbangan, yaitu: kemampuan setiap peserta didik berbeda-beda; fasilitas (sarana) setiap sekolah berbeda; dan daya dukung setiap sekolah berbeda. Hal tersebut juga didukung oleh Permendiknas (2007) bahwa penilaian hasil belajar oleh satuan pendidikan yaitu meliputi menentukan KKM setiap mata pelajaran dengan memperhatikan karakteristik peserta didik, karakteristik mata pelajaran, dan kondisi satuan pendidikanmelalui rapat dewan pendidik (Permendiknas 2007). SMK Giki 1 Surabaya menetapkan KKM mata pelajaran fisika materi impuls dan momentum yaitu 72 berdasarkan rata-rata tiap indikator materi impuls dan momentum dengan memperhatikan kompleksitas materi sebesar 66,6; daya dukung sebesar 57,1; dan intake siswa sebesar 95,2. Pembelajaran dinyatakan efektif didasarkan pada kriteria keefektifan pembelajaran di SMK Giki 1 Surabaya yaitu secara klasikal apabila $70 \%$ dari jumlah siswa telah mencapai nilai KKM. Berdasarkan hasil analisis dapat diketahui sebesar $80 \%$ mencapai KKM. Dari hasil tersebut dapat disimpulkan bahwa pembelajaran dengan menggunakan modul fisika berbasis SAVI materi impuls dan momentum dinyatakan efektif. Hasil ini relevan dengan penelitian yang dilakukan oleh Lorinda (2013) yang menunjukkan bahwa model pembelajaran SAVI berbantuan CD Pembelajaran lebih efektif terhadap kemampuan komunikasi matematika dan ada interaksi model pembelajaran dan gaya belajar terhadap kemampuan komunikasi matematika.

\section{Kesimpulan dan Rekomendasi}

Kesimpulan dari hasil penelitian dan pengembangan adalah:

1. Karakteristik modul fisika berbasis SAVI untuk meningkatkan motivasi siswa pada pokok bahasan impuls dan momentum dikembangkan berdasarkan prosedur pengembangan Model 4-D (four D Model) yang dikembangkan oleh Tiagarajan (1974) dengan melalui empat tahap yaitu pendefinisian (define), perancangan (design), pengembangan (develop), dan penyebaran (disseminate). Modul berupa modul cetak dikembangkan dengan memuat empat gaya belajar yaitu somatik (somatic), auditori(auditory), visualisasi (visualization), dan intelektual (intellectually) untuk meningkatkan motivasi siswa dalam belajar yang ditunjukkan dengan ikon tertentu. Aspek motivasi yang ditingkatkan yaituperhatian, relevansi, percaya diri, dan kepuasan. Modul fisika berbasis SAVI merupakan modul yang dapat membantu siswa dalam mengontruksi pengetahuan sesuai gaya belajar masingmasing siswa. Pembelajaran SAVI menekankan bahwa belajar haruslah memanfaatkan semua alat indera yang dimiliki siswa.

2. Modul fisika berbasis SAVI telah divalidasi oleh tiga validasi ahli, dua teman sejawat dan dua guru fisika SMK. Modul yang dikembangkan dinyatakan layak. Berdasarkan hasil validasi dan dianalisis menggunakan cut off scorepersentase keidealan keseluruhan aspek yaitu sebesar $85,0 \%$ masuk dalam kategori layak. Selain hasil validasi, kelayakan modul juga didukung oleh 
hasil angket keterbacaan modul oleh siswa dalam uji coba terbatasmodul dinyatakan layak $(75,4 \%)$ dan respons guru dalam tahap penyebaran menyatakan modul layak digunakan $(79,2 \%)$.

3. Modul efektif digunakan dalam pembelajaran fisika dengan $80 \%$ nilai hasil belajar siswa mencapai KKM. Motivasi siswa setelah diberikan pembelajaran dengan menggunakan modul fisika berbasis SAVI meningkatberdasarkan hasil perhitungan $\mathrm{N}$-gain sebesar 0,67 yang termasuk dalam kategori peningkatan sedang.

\section{Daftar Pustaka}

Daryanto. (2013). Menyusun Modul (Bahan Ajar Untuk Guru Dalam Mengajar). Yogyakarta: Penerbit Gava Media.

Gilakjani, A.P. (2011). Visual, Auditory, Kinaesthetic Learning Style and Their Impacts on English Language Teaching. Journal of Studies in Education, 2(1), pp.104-113.

Keller. The ARCS Model: Attention, Relevance, Confidence, and Satisfaction. Tersedia pada:

http://sphweb.bumc.bu.edu/otlt/teachin gLibrary/Learning\%20Theory/ARCSin tegrated_handout.pdf. Diakses pada tanggal 28 September 2015.

Lorinda, L. (2013). Keefektifan Model Pembelajaran SAVI Terhadap Kemampuan Komunikasi Matematika. Unnes Journal of Mathematics Education 2 (1) (2003). ISSN 22526927.

Menteri Pendidikan Nasional. (2006). Permendiknas No 22 Tahun 2006 Tentang Standar Isi untuk Satuan Pendidikan Dasar dan Menengah. Jakarta.

(2007). Permendiknas No 20 Tahun 2007 Tentang Standar Penilaian Pendidikan. Jakarta.

Novitayani, L. (2015). Pengembangan Modul Fisika Berbasis Somatic, Auditory, Visual, Intellectual (Savi) Untuk
Meningkatkan Kreativitas Belajar Siswa Kelas X SMA/MA Dengan Topik Kalor Dan Perpindahannya. Tesis Tidak Dipublikasikan, Universitas Sebelas Maret: Surakarta.

Pratiwi, S.N. (2013). Perbedaan Hasil Belajar Fisika Menggunakan Model Temuan Terbimbing Disertai Pendekatan SAVI (Somatis, Auditory, Visual, Intelectual) di SMA Negeri 1 Kencong. Jurnal Pendidikan Fisikia, Vol. 2 No. 2, September 2013, hal 244-250.

Purwadarminto. (1989). Kamus Besar Bahasa Indonesia. Jakarta: Balai Pustaka.

Shoimin, A. (2013). Model Pembelajaran Inovatif dalam Kurikulum 2013. Yogyakarta: Ar-Ruzz Media.

Soewandi, S., et al. (2005). Perspektif Pembelajaran di Berbagai Bidang. Yogyakarta: USD.

Sudira, P. (2006). Pembelajaran di SMK. Departemen Pendidikan Nasional. Direktorat jenderal Manajemen Pendidikan Dasar dan Menengah. Direktorat Pembinaan Sekolah Menengah Kejuruan.

Sudjana, N. (2002). Penilaian Hasil Proses Belajar Mengajar. Bandung: Remaja Rosdakarya.

Thiagarajan, S. Semmel, D.S \& Semmel, MI. (1974). Instructional Development for Training Teachers of Exceptional Children. Indiana: Indiana University Bloomington.

Trianto. (2009). Mendesain Model Pembelajaran Inovatif Progresif: Konsep, Landasan, dan Implementasinya pada Kurikulum Tingkat Satuan Pendidikan (KTSP). Jakarta: Kencana.

Uno, H.B. (2014). Teori Motivasi dan Pengukurannya. Jakarta: Bumi Aksara.

Winnie, S. (2009). Pendekatan Kombinasi Metode AHP dan Metode Cut Off Point pada Tahap Analisis Keputusan Perancangan Sistem Informasi Penjualan PT.X. http://eprints.undip.ac.id. Diakses 10 Mei 2016 